\title{
PENGEMBANGAN KURIKULUM BAHASA ARAB DI MADRASAH BERBASIS KARAKTER
}

\author{
Sahkholid Nasution \\ Fakultas Ilmu Tarbiyah dan Keguruan (FITK) UIN Sumatera Utara
}

\begin{abstract}
Moral decadence of the nation today are very concerned. Not only the students in the school, but also students in Madrasah, the postscript learning Islamic education and Arabic language more than in school. Therefore, the cultivation of students' character should be done through the development of the curriculum in all subjects including Arabic lessons. This paper aims to describe how the Arabic language curriculum development to shape the character of the students. The methodology used was a qualitative approach with descriptive-analytic method. Among its conclusions: (1). Selection of teaching materials from the texts that are full of character values. (2). Mahfuzhat maximize learning. (3). The routine of Arabic. (4). Modeling and (5). Conditioning.
\end{abstract}

Keywords: curriculum development, arabic language, character education, curriculum 2013

\begin{abstract}
Abstrak: Dekadensi moral anak bangsa saat ini sangat mengkhawatirkan. Tidak saja siswa di sekolah, tetapi juga siswa di Madrasah, yang nota bene belajar Pendidikan Agama Islam dan Bahasa Arab(BA) lebih banyak dibanding di Sekolah. Karena itu, penanaman karakter siswa hendaknya dilakukan melalui pengembangan kurikulum semua mata pelajaran, termasuk pelajaran BA. Tulisan ini bertujuan untuk mendeskripsikan cara pengembangan kurikulum BA untuk membentuk karakter siswa. Pengembangan Kurikulum dilakukan dengan: (1) memanfaatkan bahan ajar dari teks-teks yang sarat dengan nilai-nilai karakter. (2) memaksimalkan pembelajaran mahfuzhat, (3) menyelenggarakan kegiatan rutin ber-BA, (4) memberikan keteladanan, dan (5) pengkondisian.
\end{abstract}

Kata Kunci: pengembangan kurikulum, bahasa Arab, karakter, kurikulum 2013.

Generasi muda adalah pemimpin masa depan. Sementara itu, peran pendidikan dalam membentuk generasi yang akan datang sangat menentukan. Karena itu, kerja sama antara trilogi pendidikan (rumah, sekolah, lingkungan masyarakat) harus terbangun secara sinergis dan kontiniu, agar terwujud generasi muda yang berkarakter. Oleh karena itu, pendidikan karakter sangat penting untuk dikembangkan karena karakter merupakan pondasi utama yang harus ditanamkan sejak dini kepada peserta didik (Hamdun, 2016:51). Tanggung 
jawab pendidikan karakter di Madrasah adalah tanggung jawab semua guru mata pelajarantermasuk guru bahasa Arab (Akla, 2016:34).

Faktor yang sangat menentukan dalam mensukseskan pendidikan sebagai motor penggerak pembentukan karakter bangsa adalah pengembangan kurikulum. Menurut Abdul Wahab (2016:37) kurikulum (manhaj) merupakan "jantung" institusi pendidikan atau sistem pembelajaran. Sedangkan menurut Muhaimin (2009: 1-2): "Kurikulum merupakan salah satu komponen pokok aktivitas pendikan, dan merupakan penjabaran dari idealisme, cita - cita, tuntutan masyarakat, atau kebutuhan tertentu. Dari kurikulum inilah akan diketahui arah pendidikan, alternatif pendidikan, fungsi pendidikan serta hasil pendidikan yang hendak dicapai dari aktivitas pendidikan. Karena itu, kurikulum selalu menjadi bahan perbincangkan yang menarik dan aktual, bahkan dikalangan masyarakt pendidikan sering muncul ungkapan bahwa "ganti materi ganti kurikulum", walaupun dalam kenyataannya tidak demikian." Karena itu, pengembangan kurikulum merupakan suatu keniscayaan, termasuk pengembangan kurikulum BA, sesuai dengan perkembangan ilmu pengetahuan dan teknologi, tuntutan sosial masyarakat, dan perkembangan global.

Pengembangan Kurikulum BA di Madrasah Berbasis Karakter merupakan salah salah satu tuntutan yang sangat urgen, mengingat: Pertama, Fenomena kenakalan siswa pada semua jenjang dan jenis pendidikan yang semakin mengkhawatirkan; Kedua, Kualitas siswa yang sangat jauh dibawah jika diukur dengan standar global; Ketiga, Tuntutan perkembangan zaman yang semakin kompleks; Keempat, Persepsi masyarakat; bahwa

kurikulum selama ini terlalu menitikberatkan pada aspek kognitif; beban siswa terlalu berat; dan kurangnya bermuatan karakter.

Pengembangan kurikulum BA di Madrasah berbasis karakter merupakan bagian dari tujuan pengembangan kurikulum itu sendiri. Oleh karena itu, proses pembelajaran Bahasa Arab (PBA) di semua jenis dan jenjang pendidikan seharusnya berlandaskan kurikulum yang mampu mengatasi dan menjawab semua tuntutan di atas.

Seiring dengan itu, permasalahan utama dalam tulisan ini adalah: Bagaimana mengembangkan kurikulum BA di Madrasah berbasis karakter? Untuk mendapatkan jawaban tentang pertanyaan itu, penulis menguraikan beberapa sub pertanyaan sebagai berikut: Apa dan bagaimana cara mengembangkan kurikulum ?, Apa itu karakter?, Apa landasan, prinsip dan proses pengembangan kurikulum BA di Madrasah berbasis karakter?.

\section{PENGEMBANGAN KURIKULUM}

Pengembangan berarti tindak lanjut dari pertumbuhan. Dalam Kamus Besar Bahasa Indonesia (1997: 473) kata pengembangan diberi makna "Proses, cara, perbuatan mengembangkan". Menurut Muhaimin (2011:1), istilah pengembangan dapat bermakna kuantitatif dan kualitatif, yang bisa dalam bentuk: 1) Memperkaya nuansa pemikiran dan terori yang ada; atau 2) Merevisi dan menyempurnakan pemikiran dan teori yang sudah ada; atau 3) Mengganti pemikiran dan teori lama dengan pemikiran dan teori baru; atau 4). Menciptakan pemikiran dan teori yang belum ada sebelumnya. Dengan demikian, jika konsep Muhaminin di atas "diamini" dan dihubungkan dengan pengembangan kurikulum BA di Madrasah, maka bisa jadi kita harus: 1) Memperkaya kurikulum BA di Madrasah berbasis karakter yang sudah ada; atau 2) Merevisi kurikulum BA di Madrasah berbasis karakter yang sudah ada; atau 3) Mengganti kurikulum BA di Madrasah berbasis karakter yang sudah ada; atau 4) Menciptakan kurikulum BA di Madrasah yang belum ada 
sebelumnya. Seiring dengan itu, kecenderungan alternatif yang dipakai dalam tulisan ini adalah poin pertama yaitu memperkaya kurikulum BA di Madrasah berbasis karakter yang sudah ada yaitu rumusan kurikulum 2013, yang walaupun kurikulum ini belum "dilabeli" seperti kurikulum 2004 dengan kurikulum KBK, kurikulum 2006 dengan KTSP, tapi fokus utama dari kurikulum 2013 ini adalah pengembangan budi pekerti atau karekter. Dengan demikian, makna pengembangan kurikulum dalam tulisan ini adalah kegiatan penyusunan (perancangan), pelaksanaan, penilaian dan penyempurnaan kurikulum.

\section{KARAKTER: PENGERTIAN DAN NILAI-NILAI Pengertian Karakter}

Kata karakter diadposi dari bahasa Inggris character yang bermakna sifat, prilaku, akhlak, tabiat, dan budi pekerti. (Andrianto, 2011:17). Menurut Kamus Besar Bahasa Indonesia (1997: 445), karakter merupakan "Sifat-sifat kejiwaan, akhlak atau budi pekerti yang membedakan seseorang dari yang lain; tabiat; watak."

Dalam kehidupan sehari-hari ada beberapa istilah yang menjadi sinonim dari kata karakter yang bisa jadi membingungkan sebagian orang. Istilah-istilah tersebut adalah Karakter, Nilai, Etika, Norma, Moral, Budi Pekerti, dan Akhlak. Untuk tahap pertama bisa dirujuk kepada makna leksikal dan/atau gramatikal dari masing-masing kata tersebut:

Nilai : Sifat-sifat (hal-hal) yg penting atau berguna bagi kemanusiaan.” (KBBI, 1997: 690)

Etika : Ilmu tentang apa yang baik dan apa yang buruk dan tentang hak dan kewajiban moral (akhlak). (KBBI, 1997: 271)

Norma : (1) Aturan atau ketentuan yg mengikat warga kelompok dl masyarakat, dipakai sebagai panduan, tatanan, dan pengendali tingkah laku yg sesuai dan berterima.

(2) Aturan, ukuran, atau kaidah yg dipakai sbg tolok ukur untuk menilai atau memperbandingkan sesuatu. (KBBI, 1997: 693).

Moral : (1) Ajaran tentang baik buruk yg diterima umum mengenai perbuatan, sikap, kewajiban, dsb; akhlak; budi pekerti; susila; atau (2) Kondisi mental yg membuat orang tetap berani, bersemangat, bergairah, berdisiplin, dsb; isi hati atau keadaan perasaan sebagaimana terungkap dalam perbuatan. (KBBI, 1997: 665).

Istilah moral biasanya dipergunakan untuk menentukan batas-batas suatu perbuatan, kelakuan, sifat dan perangai dinyatakan benar, salah, baik, buruk, layak atau tidak layak, patut maupun tidak patut.

Budi Pekerti: Tingkah laku; perangai; akhlak (KBBI, 1997: 150).

Akhlak : Budi pekerti; kelakuan. (KBBI, 1997: 17). Dengan kata lain, akhlak adalah nilainilai yang mengatur tata cara hidup manusia sesuai dengan ajaran agama. Sehingga dalam berbuat baik untuk kepentingan individu maupun untuk kepentingan bermasyarakat ada aturan yang harus dipatuhi.

Melalui defenisi-defenisi di atas dapat diketahui bahwa nilai-nilai kehidupan adalah norma-norma yang berlaku dalam masyarakat, misalnya adat kebiasaan, dan sopan santun, seperti: mengakui persamaan derajat, hak, dan kewajiban antar sesama manusia, mengembangkan sikap tenggang rasa, tidak semena-mena terhadap orang lain, berani membela kebenaran dan keadilan, dll. Dengan demikian, keterkaitan antara nilai, moral, sikap dan tingkah laku akan tampak dalam pengamalan nilai-nilai. Dengan kata lain, nilainilai perlu dikenal terlebih dulu, kemudian dihayati dan didorong oleh moral, baru akan 
berbentuk sikap tertentu terhadap nilai-nilai tersebut dan pada akhrinya terwujud tingkah laku sesuai dengan nilai-nilai yang dimaksud. (Sunarto dan Hartono, 1999: 170).

Sementara itu, perbedaan antara akhlak dengan moral dan etika dapat dilihat dari dasar penentuan atau standar ukuran baik dan buruk yang digunakannya. Standar baik dan buruk akhlak berdasarkan Al-Qur'an dan Sunnah Rasul, sedangkan moral dan etika berdasarkan adat istiadat atau kesepakatan yang dibuat oleh suatu masyarakat, jika masyarakat menganggap suatu perbuatan itu baik maka perbuatan itu menjadi baik. Dengan demikian, standar nilai moral dan etika bersifat lokal dan temporal, sedangkan standar akhlak bersifat universal dan abadi. Dalam pandangan Islam, akhlak merupakan cermin dari apa yang ada dalam jiwa seseorang. Karena itu, akhlak yang baik merupakan dorongan dari keimanan seseorang, sebab keimanan harus ditampilkan dalam prilaku nyata.

Karakter dapat dianggap sama dengan akhlak dan kepribadian. Menurut Samani dan Hariyanto (2011: 41), karakter dimaknai sebagai "Cara berpikir dan berprilaku yang khas tiap individu untuk hidup dan bekerja sama, baik dalam lingkungan keluarga, masyarakat bangsa, dan Negara. Individu yang berkarakter baik adalah individu yang dapat membuat keputusan dan siap mempertanggungjawabkan setiap akibat dari keputusannya."

Yang menjadi point penting dalam definisi ini adalah cara berpikir dan berprilaku dalam hubungannya dengan lingkungan. Disisi lain, cara berpikir dan berprilaku itu sendiri dipengaruhi oleh lingkungan. Hal ini senada dengan dua definisi berikut: Pertama, Sjarkawi (2006: 11) "Ciri atau karakteristik atau gaya atau sifat khas dari diri seseorang yang bersumber dari bentukan - bentukan yang diterima dari lingkungan, misalnya keluarga pada masa kecil, dan juga bawaan seseorang sejak lahir." Kedua, Samani dan Harianto (2011: 247), mengatakan bahwa: "Karakter adalah nilai dasar yang membangun pribadi seseorang, terbentuk baik karena pengaruh hereditas maupun pengaruh lingkungan, yang membedakannya dengan orang lain, serta diwujudkan dalam sikap dan perilaku."

Dengan demikian, dapat disimpulkan bahwa karakter adalah prilaku yang khas pada setiap individu dalam hubungannya dengan Tuhan, diri sendiri, dan lingkungan disekitarnya yang terwujud dalam pikiran, sikap, perasaan, perkataan, dan perbuatan berdasarkan norma-norma agama, hukum, tata karma, budaya, adat istiadat dan estetika. Dan karakter sangat dipengaruhi oleh dua faktor; internal dan eksternal (lingkungan) yang mencakup: lingkungan pendidikan dan sosial.

\section{Nilai-nilai Karakter}

Indonesia Heritage Foundation -sebagaimana dikutip oleh Madjid dan Andayani (2011: 42-43) - merumuskan sembilan karakter dasar yang menjadi tujuan pendidikan karakter: "1) cinta kepada Allah dan semesta beserta isinya; 2) tanggung jawab, disiplin dan mandiri; 3) jujur; 4) hormat dan santun; 5) kasih sayang, peduli, dan kerja sama; 6) percaya diri, peduli, dan kerjas sama; 7) keadilan dan kepemimpinan; 8) baik dan rendah hati; 9) toleransi, cinta damai dan persatuan." Sementara Character Counts di Amerika sebagaimana dikutip oleh Madjid dan Andayani (2011:43) - mengidentifikasikan karakterkarakter yang menjadi pilar yaitu: 1) dapat dipercaya; 2) rasa hormat dan perhatian; 3) tanggung jawab; 4) jujur; 5) peduli; 6) kewarganegaraan; 7) ketulusan; 8) berani; 9) tekun; 10) integritas. Antara rumusan Indonesia Heritage Foundation dan Character Counts di atas tentu saling melengkapi.

Banyak nilai karakter yang dapat digali dari ajaran agama Islam dan khazanah budaya bangsa Indonesia. Namun demikian, nilai-nilai tersebut hanya akan dapat "bernilai" jika 
mampu ditransformasikan ke semua anak bangsa dan kemudian dapat mereka internalisasikan dalam diri masing-masing. Proses transformasi dan internalisasi nilai-nilai itu hanya akan berhasil jika dilakukan melalui pendidikan. Koesoema (2010: 92) menguatkan bahwa, "Perubahan dapat dilakukan melalui proses pendidikan."

\section{PENGEMBANGAN KURIKULUM BA BERBASIS KARAKTER}

Pengembangan kurikulum BA sama dengan pengembangan kurikulum lainnya. Oleh karena itu, mau tidak mau harus bersentuhan dengan asas-asas pengembangan kurikulum secara umum, yaitu: landasan filosofis, landasan religius, landasan sosial budaya, landasan perkembangan IPTEK.

\section{Landasan Filosofis}

Untuk mewujudkan kurikulum BA di Madrasah berbasis karakter hendaknya filosofi pendidikan yang dianut adalah filsafat pendidikan yang berbasis pada nilai-nilai luhur, nilai akademik, kebutuhan peserta didik dan masyarakat. Untuk itu, landasan filosofinya adalah: Pertama, Pancasila dan UUD 1945 merupakan asas utama pengembangan kurikulum berbasis karekter. Kedua, Tujuan Pendidikan Nasional sebagaimana dimuat dalam Undangundang No. 20 Tahun 2003, Pasal 3 bahwa "Pendidikan Nasional berfungsi mengembangkan kemampuan dan membentuk watak serta peradaban bangsa yang bermartabat dalam rangka mencerdaskan kehidupan bangsa, bertujuan untuk berkembangnya potensi peserta didik agar menjadi manusia yang: beriman dan bertaqwa kepada Tuhan YME; berakhlak mulia; sehat; berilmu; cakap; kreatif; mandiri dan menjadi warga negara yang demokratis serta bertanggung jawab." Dengan demikian, PBA di Madrasah maupun Sekolah harus "direkayasa" supaya mampu mewujudkan Tujuan Pendidikan Nasional itu.

Ketiga, PP No. 32 Tahun 2013 Pasal 2 Ayat 1a, perubahan atas PP. No. 19 Tahun 2005 tentang Standar Pendidikan Nasional, yang sudah berlaku sejak 7 Mei 2013: "Standar Nasional Pendidikan digunakan sebagai acuan pengembangan kurikulum untuk mewujudkan tujuan pendidikan nasional." Keempat, tujuan Kurikulum 2013 adalah "mempersiapkan insan Indonesia untuk memiliki kemampuan hidup sebagai pribadi dan warganegara yang produktif, kreatif, inovatif, dan afektif serta mampu berkontribusi pada kehidupan bermasyarakat, berbangsa, bernegara dan peradaban dunia." Produktif, kreatif, inovatif, dan afektif serta mampu berkontribusi pada kehidupan adalah sebagian dari beberapa karakter yang harus dikembangkan melalui pendidikan, dan satunya adalah PBA.

Dengan demikian, secara filosofis pengembangan kurikulum BA di Indonesia memiliki dasar yang jelas dalam rangka pembentukan karakter bangsa, seperti peningkatan iman dan takwa, berakhlak mulia; peningkatan potensi, kecerdasan, dan minat peserta didik; beragama; dan memiliki sikap cinta tanah air. Seiring dengan itu, rekonstruksi kurikulum BA di Madrasah -secara khusus- merupakan upaya pengembangan pendidikan karakter bangsa (nation character building).

\section{Landasan Religius}

Di dalam Al-Qur'an tidak ditemukan ayat yang berbicara secara tegas/langsung tentang konsep pengembangan kurukulum BA berbasis karakter. Namun, jika dipahami secara mendalam ditemukan sejumlah ayat yang bisa dianggap memiliki hubungan dengan semangat pengembangan kurukulum BA berbasis karakter. Inilah yang penulis jadikan 
sebagai landasan religuis dalam pengembangan kurukulum BA berbasis karakter. Diantara ayat-ayat dimaksud adalah:

a) QS. An-Nisâ: 9.

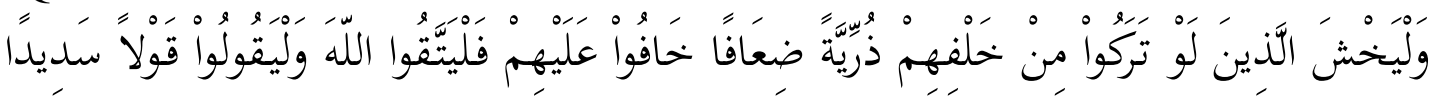

"Dan hendaklah takut kepada Allah orang-orang yang seandainya meninggalkan di belakang mereka anak-anak yang lemah, yang mereka khawatir terhadap (kesejahteraan) mereka. Oleh sebab itu hendaklah mereka bertakwa kepada Allah dan hendaklah mereka mengucapkan perkataan yang benar."

Salah satu upaya yang harus ditempuh untuk menghindari generasi yang lemah adalah mempersiapkan kurikulum pendidikan yang jelas demi menata masa depan generasi yang gemilang.

b) QS. Al-Furqân: 74:

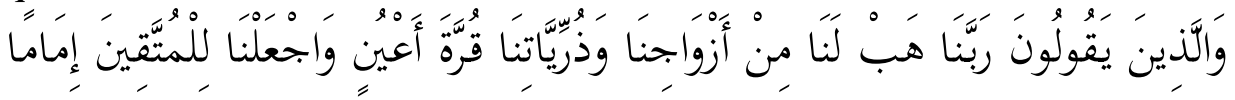

“ Dan orang-orang yang berkata: "Ya Tuhan kami, anugerahkanlah kepada kami istri-istri kami dan keturunan kami sebagai penyenang hati (kami), dan jadikanlah kami imam bagi orang-orang yang bertakwa."

Keturunan yang mampu menjadi penyenang hati tentunya generasi yang berkarakter.

c) QS. Asy-Syu'ara': 192-195

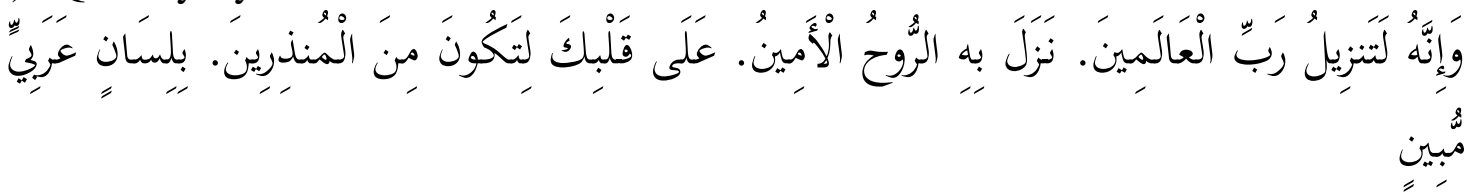

“Dan sesungguhnya Al Qur'an ini benar-benar diturunkan oleh Tuhan semesta alam, dia dibawa turun oleh Ar-Ruh Al Amin (Jibril), ke dalam hatimu (Muhammad) agar kamu menjadi salah seorang di antara orang-orang yang memberi peringatan, dengan BA yang jelas."

Kalimat "dengan BA yang jelas" menunjukkan bahwa BA itu mudah dipelajari. Oleh karena itu, perlu dikembangkan sikap positive thingking terhadap BA.

Tentu pelabelan dan pengelompokan tema-tema dari ayat-ayat tersebut bukanlah dalam kontek asbabun nuzul dari ayat-ayat tersebut, tetapi berdasarkan usulan penulis yang mungkin saja terkesan "dipaksakan". Namun demikian, dalam konteks penafsiran ayat boleh saja dilakukan sepanjang tidak bertentangan dengan ajaran Islam itu sendiri.

\section{Landasan Sosiol-Budaya}

Landasan sosial-budaya dalam pengembangan kurikulum BA berbasis karakter dapat dilihat dalam poin-poin berikut: Pertama, BA merupakan sarana komunikasi global bagi mayoritas penduduk Timur Tengah dan negara lain yang mayoritas penduduknya beragama Islam. Bahasa ini berfungsi mengungkapkan keyakinan, pengetahuan, perasaan, dan pengalaman para penuturnya. Kedua, sebagian besar penduduk Indonesia memeluk Agama Islam yang sumber pokok ajarannya ialah al Qur'an dan al Hadits yang menggunakan BA. Di samping itu, salah satu jenis ibadah umat Islam, yaitu ibadah haji, mesti dilakukan di Arab Saudi yang bahasa pengantarnya BA. Ketiga, meskipun pengaturan pendidikan bersifat desentralistik, kualitas pendidikan antardaerah tidak boleh mengalami kesenjangan. 
Karena itu perlu dirumuskan standar kompetensi yang berlaku secara nasional. Standar inilah yang merupakan seperangkat kompetensi yang merupakan landasan bagi kualitas pendidikan. Standar mengungkapkan apa yang semestinya diketahui dan apa yang dapat dilakukan siswa.

\section{Landasan Perkembangan IPTEK}

Pengembangan kurikulum BA berbasis karakter dapat memperhatikan perkembangan ilmu pengetahuan dan teknologi. Bahkan hendaknya menyesuaikan diri dengan perkembangan ilmu dan teknologi. Misalnya untuk peningkatan kemahiran istima', bisa dirancang software yang bisa dimanfaatkan oleh guru dan siswa dalam PBA di labolatorium bahasa atau digunakan secara mandiri. Sehingga terbentuk kemampuan siswa dalam berBA baik secara reseptif maupun produktif.

\section{Prinsip-Prinsip Pengembangan Kurikulum BA di Madrasah Berbasis Karakter}

Merujuk pendapat Sauri (2013 tentang prinsip-prinsip pengembangan kurikulum berbasis karakter, maka dapat dirumuskan bahwa prinsip-prinsippengembangan kurikulum BA di Madrasah berbasis karakteradalah sebagai berikut:

Berpusat pada potensi, perkembangan, kebutuhan, dan kepentingan peserta didik dan lingkungannya. Kurikulum BA di Madrasah dikembangkan berdasarkan prinsip bahwa peserta didik memiliki posisi sentral untuk mengembangkan kompetensinya agar menjadi manusia yang beriman dan bertakwa kepada tuhan yang Maha Esa, berakhlak mulia, sehat, berilmu, cakap, kreatif, mandiri dan menjadi warga negara yang demokratis serta bertanggung jawab. Untuk mendukung pecapaian tujuan tersebut pengembangan kompetensi peserta didik disesuaikan dengan potensi, perkembangan, kebutuhan, dan kepentingan peserta didik serta tuntutan lingkungan.

Beragam dan terpadu. Kurikulum BA di Madrasah dapat dikembangkan dengan memperhatikan keragaman karakteristik peserta didik, kondisi daerah, jenjang dan jenis pendidikan, serta menghargai dan tidak diskriminatif terhadap perbedaan agama, suku, budaya, adar istiadat, status sosial ekonomi, dan jender. Kurikulum meliputi substansi komponen muatan wajib kurikulum, muatan lokal, dan pengembangan diri secara terpadu, serta disusun dan keterkaitan serta kesinambungan yang bermakna dan tepat antara subtansi.

Tanggap terhadap perkembangan ilmu pengetahuan, teknologi dan seni. Kurikulum BA di Madrasah dikembangkan atas dasar kesadaran bahwa ilmu pengetahuan, teknologi dan seni yang berkembang secara dinamis. Semangat dan isi kurikulum, memberkan pengalaman belajar peserta didik untuk mengikuti dan memanfaatkan perkembangan ilmu pengetahuan, teknologi, dan seni.

Relevan dengan kebutuhan kehidupan. Pengembangan kurikulum BA di Madrasah dilakukan dengan melibatkan strakeholders untuk menjamin relevansi pendidikan dengan kebutuhan kehidupan, termasuk di dalamnya kehidupan kemasyarakatan, dunia usaha dalam dunia kerja.

Menyeluruh dan berkesinambungan. Substansi kurikulum mencakup keseluruhan dimensi kompetensi, bidang kajian keilmuan dan mata pelajaran yang direncanakan dan disajikan secara berkesinambungan antarsesama jenjang pendidikan. 
Belajar sepanjang hayat. Pengembangan kurikulum BA di Madrasah dapat diarahkan kepada proses pengembangan, pembudayaan, dan pemberdayaan peserta didik yang berlangsung sepanjang hayat.

Seimbang antara kepentingan nasional dan kepentingan daerah. Pengembangan kurikulum BA di Madrasah hendaknya memerhatikan kepentingan nasional dan kepentingan daerah untuk membangun kehidupan bermasyarakat, berbangsa dan bernegara.

\section{Proses Pengembangan Kurikulum BA Berbasis Karakter di Madrasah Pengintegrasian Nilai-nilai Karakter pada Mata Ajar BA}

Salah satu prinsip pengembangan kurikulum berbasis karakter -seperti tersebut di atasadalah menyeluruh dan berkesinambungan. Hasan (2010: 11) mengatakan bahwa: "Pada prinsipnya, pengembangan budaya dan karakter bangsa tidak dimasukkan sebagai pokok bahasan tetapi terintegrasi ke dalam mata pelajaran, pengembangan diri, dan budaya sekolah."

Sebagai contoh, nilai-nilai karakter dicantumkan dalam silabus dan RPP. Pengembangan nilai-nilai itu dalam silabus ditempuh melalui cara-cara berikut ini: Pertama, Mengkaji Kompetensi Dasar (KD) pada Standar Isi (SI) untuk menentukan apakah nilai-nilai karakter yang tercantum itu sudah tercakup di dalamnya; Kedua, Mencantumkankan nilai-nilai karakter bangsa itu ke dalam silabus; Ketiga, Mencantumkan nilai-nilai yang sudah tertera dalam silabus ke dalam RPP; Keempat, Mengembangkan proses pembelajaran peserta didik secara aktif yang memungkinkan peserta didik memiliki kesempatan melakukan internalisasi nilai dan menunjukkannya dalam perilaku yang sesuai; dan Kelima, Memberikan bantuan kepada peserta didik, baik yang mengalami kesulitan untuk menginternalisasi nilai maupun untuk menunjukkannya dalam perilaku. (Sauri, 2013). Oleh karena itu, guru dan sekolah perlu mengintegrasikan nilai-nilai yang dikembangkan dalam pendidikan budaya dan karakter bangsa ke dalam silabus dan RPP yang sudah ada.

\section{Program Pengembangan Diri}

Program pengembangan diri yang dimaksud dalam hal ini adalah sejumlah kegiatan yang dirancang untuk mendukung kemampuan paserta didik dalam menguasai keterampilan berBA. Untuk lebih jelasnya, dalam hal PBA di Madrasahprogram pengembangan diri tersebut dapat dilakukan dengan bentuk-bentuk sebagai berikut:

1) Kegiatan rutin berBA. Karakter murid dapat dibentuk melalui PBA yang dilakukan secara rutin. Rutin dalam arti bisa setiap hari atau beberapa hari dalam seminggu, sebulan, semesteran bahkan tahunan. Contoh kegiatan ini adalah ber-BA dalam upacara pada hari besar Islam/Kenegaraan, ber-BA pada setiap hari Senin, Rabu dan Jumat, menyapa dengan tidak kurang dari 3 kalimat setiap kali bertemu dengan guru, tenaga kependidikan, atau teman. dll.

2) Keteladanan pendidik dan tenaga kependidikan. Keteladanan adalah perilaku dan sikap guru dan tenaga kependidikan yang lain dalam memberikan contoh terhadap tindakan-tindakan yang baik sehingga diharapkan menjadi panutan bagi peserta didik untuk mencontohnya. Dalam hal proses pengembangan kurikulum BA di Madrasah berbasis karakter, guru dan tenaga kependidikan harus mampu menjadi panutan siswa dalam ber-BA. Oleh karena itu, guru BA diharapkan mampu ber-BA disetiap saat atau paling tidak saat mengajar BA. Demikian juga dukungan dari 
pihak tenaga kependidikan, sangat diperlukan. Mereka diharapkan mampu menggunakan BA setiap kali memberikan pelayanan administratif kepada setiap siswa. Jika kondisi ini terwujud, motivasi siswa untuk menguasai BA akan tumbuh subur, seiring dengan keteladanan pendidik dan tenaga kependidikan yang mereka temukan setiap hari di madrasah.

3) Pengkondisian lingkungan ber-BA (biah arabiyah) yang baik. Untuk mendukung keterlaksanaan pendidikan karakter melalui pengembangan kurikulum BAdi Madrasah maka madrasah harus dikondisikan sebagai pendukung kegiatan itu. Madrasah harus mencerminkan kehidupan nilai-nilai budaya dan karakter bangsa yang diinginkan melalui penggunaan BA. Misalnya, toilet yang selalu bersih, bak sampah ada di berbagai tempat dan selalu dibersihkan, sekolah terlihat rapi dan alat belajar ditempatkan teratur.Hal itu semua disertai dengan tulisan-tulisan berBA tentang pentingnya kebersihan dan kerapian. Biah Arabiyah tidak hanya mendukung tercapainya keberhasilan pendidikan karakter akan tetapi menurut Khasairi (2011:10) menjadi salah satu faktor para siswa memperoleh input kebahasaaraban lebih maksimal menuju keberhasilan mereka dalam belajar BA.

\section{Meluruskan Kembali Paradigma Tujuan PBA}

Walaupun dalam KBK, KTSP dan K-13 telah dirumuskan secara tegas bahwa PBA dimaksudkan untuk menguasai BA dengan segala aspeknya, namun masih banyak yang beranggapan bahwa BA hanya untuk kepentingan agama semata. Padahal penguasaan BA tidak saja untuk memahami agama atau agar dianggap ahli di bidang Agama Islam, tetapi juga untuk aspek-aspek yang lebih luas, seperti kepentingan politik, ekonomi, dan budaya. Setiap guru BA hendaknya dapat menunjukkan kepada siswa contoh konktit bahwa dengan menguasai BA, Indonesia dan warganya bisa berperan aktif dan kontributif dalam percaturan politik dan ekonomi dunia, serta budaya bangsa ini bisa diperkenalkan ke berbagai negara lain. Dalam pengembangan disain sistem pengajaran, Khasairi (2013:60) menyatakan bahwa guru harus memperhatikan karakteristik PBA sebagai alat komunikasi maupun untuk mempelajari naskah-naskah keislaman (termasuk pendidikan karakter) yang diajarkan secara terintegrasi.

Rumusan tujuan PBA di Madrasah telah diatur dalam Permenag No. 912 Tahun 2013 tentang Kurikulum Pendidikan Agama Islam dan BA. Di dalam Permenag tersebut disebutkan bahwa mata pelajaran BA di Madrasah Ibtidaiyah, Tsanawiyah dan Aliyah, termasuk peminatan ilmu-ilmu keagamaan, memiliki tujuan sebagai berikut: Pertama, Mengembangkan kemampuan berkomunikasi dalam BA, baik lisan maupun tulis, yang mencakup empat kecakapan berbahasa, yakni menyimak (istimâ'), berbicara (kalâm), membaca (qirâ'ah) dan menulis (kitâbah).Kedua, Menumbuhkan dan mengembangkan kesadaran tentang pentingnya BA sebagai salah satu bahasa asing untuk menjadi alat utama belajar, khususnya dalam mengkaji sumber-sumber ajaran Islam; Ketiga, Mengembangkan pemahaman tentang saling keterkaitan antara bahasa dan budaya serta memperluas cakrawala budaya. Dengan demikian, peserta didik diharapkan memiliki wawasan lintas budaya dan melibatkan diri dalam keragaman budaya.

Namun demikian, seiring dengan tuntutan globalisasi PBA harus diarahkan kepada: Pertama, Keterampilan berinteraksi sosial. Artinya siswa dapat berkomunikasi secara lisan dan tertulis dalam situasi yang beragam dengan masyarakat dari latar belakang budaya dan bahasa yang berbeda; Kedua, Keterampilan mengakses informasi. Maksudnya, siswa 
memiliki kemahiran dalam memperoleh informasi dari berbagai sumber yang berbeda dan media yang bervariasi serta mampu menggunakannya; Ketiga, Keterampilan presentasi. Siswa memiliki kemahiran dalam mempresentasikan informasi dan gagasan secara sistematis dalam berbagai bentuk yang bervariasi, baik secara lisan maupun tertulis, tentang berbagai topik; Keempat, Apresiasi sastra. Siswa mengapresiasi sastra lisan dan tulis serta mengembangkan kepekaannya terhadap nilai-nilai budaya yang terkandung dalam karya sastra. Kelima, Bahasa dan budaya. Siswa mengapresiasi karakteristik bahasa dan perbedaan antarbahasa. Keterampilan ini dikenal dengan cross-cultural understanding yang lazim disingkat CCU. (Syihabuddin, 2013).

Karena itu, pendidikan bahasa perlu dilakukan dengan berbasis pada standar tertentu. Standar ini merumuskan apa yang diharapkan dapat dilakukan siswa pada berbagai tingkat performansi dalam berbagai keterampilan berbahasa. Standar yang harus dirumuskan dalam PBA berbasis karakter antara lain Standar Kompetensi Lulusan (SKL), Kompetensi Inti dan Kompetensi Dasar (KD). Dalam kurikulum 2013, sebagaimana tertuang dalam Lampiran Mendikbud No. 54 Tahun 2013 Tentang Standar Kompetensi Lulusan (SKL) Pendidikan Dasar dan Menengah, bahwa SKL siswa diurut dari sikap, pengetahuan dan keterampilan. Hal ini berbeda dengan rumusan domain SKL pada kurikulum sebelumnya yaitu pengetahuan, sikap dan keterampilan. Untuk masing-masing domain dibuat proses yang berbeda-beda. Sementara itu, domain sikap memiliki tiga sasaran yaitu terhadap individu, sosial dan alam. Domain pengetahuan mencakup obyek dan subyek, dan domain keterampilan mencakup keterampilan abstrak dan kongkrit.

\section{Penambahan Jam Pelajaran BA}

Ketersediaan jam pelajaran yang memadai salah satu faktor penentu keberhasilan pembelajaran. Hasil yang diperoleh dengan waktu yang singkat tentu tidak sama dengan hasil yang diperoleh dengan ketersediaan waktu yang cukup memadai. Selama ini jumlah jam PBA di Madrasah dan sekolah hanya 2 jam dalam seminggu. Kurikulum 2013 mengalokasikan 8-12 jam pelajaran perminggu sebagaimana dapat dilihat dalam tabel 1 .

Pada hakikatnya, jumlah jam belajar BA seperti tersebut di atas belum mendukung penanaman karakter. Oleh karena itu, setiap guru diharapkan kreatif memanfaatkan waktu tambahan walau hanya melalui praktek BA setiap kali berjumpa dan berkomunikasi dengan siswa-siswanya.

Tabel 1 Alokasi Jam Pelajaran BA di Madrasah

\begin{tabular}{llccccccc}
\hline No & \multicolumn{1}{c}{ Jenjang Pendidikan } & \multicolumn{9}{c}{ Alokasi Waktu } & Total \\
& & 1 & 2 & 3 & 4 & 5 & 6 & \\
\hline 1 & Ibtidaiyah & 2 & 2 & 2 & 2 & 2 & 2 & 12 \\
2 & Tsanawiyah & 3 & 3 & 3 & & & & 9 \\
3 & Aliyah (Semua Jur.) & 4 & 2 & 2 & & & 8 \\
& $-\quad$ Peminatan Bahasa & 3 & 4 & 4 & & & 11 \\
& $-\quad$ Peminatan Agama & 2 & 3 & 3 & & & 8 \\
\hline
\end{tabular}




\section{Penyusunan Materi PBA yang Sarat dengan Nilai-nilai Karakter}

Peranan buku ajar atau sumber belajar sangat menentukan keberhasilan pembelajaran. Setiap guru dan praktisi pendidikan lainnya diberikan hak yang sama untuk menyusun dan mengembangkan buku ajar sesuai dengan kurikulum yang ditetapkan oleh pemerintah pusat. Muatan buku ajar yang sarat nilai-nilai karekter dipandang sangat efisien dalam membentuk karakter peserta didik.

Sebagai contoh, penyusunan dan pengembangan bahan ajar dalam PBA berbasis karakter bisa dilakukan dengan: Pertama, Pemilihan bahan istima' muhadatsah, qira'ah dan kitab dari teks-teks yang sarat dengan nilai-nilai karakter. Kedua, Memaksimalkan pembelajaran mahfuzhat (kata-kata mutiara) dalam BA.

Disadari bahwa langkah pertama ini, dalam K-13, ruang gerak guru lebih sempit, karena teks buku BA telah disusun dan disiapkan oleh Kementerian Agama RI, sementara langkah kedua, ruang kreatifitas guru masih luas. Misalnya, dalam buku BA untuk Madrasah Tsanawiyah K-13 pada التعريف بالعاملين في المدرسة dengan judul guru dapat menanamkan nilai-nilai karakter kepada siswa melalui pengungkapan beberapa mahfuzhat di sela-sela pembelajaran topik ini. Diantaranya:

Siapa yang bersungguh pasti berhasil

Kesuksesandiperoleh setelah bersusah payah

Siapa yang menanam pasti memanen

Siapa banyak berbuat baik, pasti banyak teman.

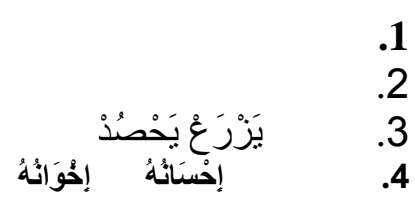

dan sejumlah mahfuzhatlain yang terkait dengan kerja. Mahfuzhat-mahfuzhattersebut dibacakan oleh guru, diikuti, dihafalkan dan diinternalisasi oleh siswa. Cara ini diasumsikan sangat tepat dalam menanamkan nilai-nilai karakter, mengingat sifatnya yang sangat singkat, padat dan berbekas di hati.

\section{Penerapan Pendekatan, Metode dan strategi yang bervariasi}

Demikian pentingnya metode, bahkan ada sebuah adigum mengatakan "Metode lebih penting daripada materi". Terlepas dari benar-tidaknya adigum ini, memang berbagai hasil penelitian menunjukkan bahwa penggunaan metode yang bervariasi dan aktif sangat mempengaruhi keberhasilan pembelajaran. Dalam PBA, guru hendaknya mampu memilih pendekatan dan menggunakan metode serta strategi yang bervariasi yang dapat mendukung pendidikan karakter, seperti penggunaan pendekatan kooperatif dengan strategi - strategi: Mencari Pasangan, Kepala Bernomor, Jigsaw, Mengurutkan Cerita / Teks, dll. Secara singkat prinsip-prinsip pengembangan metode PBA berbasis karakter dalam konsep kurikulum 2013 adalah sebagai berikut: a) melibatkan proses mental dan fisik; b) bervariasi dan berpusat pada peserta didik; c) mengembangkan kreatifitas perserta didik; d) menyenangkan dan menantang; e) bermuatan nilai, etika, estetika, logika dan kinestetika; f) menyediakan pengalaman belajar yang beragam.

\section{Pemilihan dan penerapan Evaluasi yang lebih kepada aspek efeksi anak didik}

Salah satu aspek yang dianggap keliru di dalam kurikulum KBK dan kurikulum yang diberlakukan sebelumnya, adalah tingginya muatan kognitif dan rendahnya muatan afektif, sehingga akhirnya terbentuk lulusan yang pintar dengan afeksi yang rendah. Karena terlalu 
menonjolkan aspek kognitif maka evaluasi yang dipakaipun banyak mengarah kepada jenis evaluasi kognitif. Padahal, penanaman karakter lebih kepada pengembangan afeksi. Oleh karena itu, jenis evaluasi PBA hendaknya memberikan porsi yang seimbang antara aspek kognitif, efeksi dan psikomotorik.

Seiring dengan itu, dalam kurikulum 2013 karakteristik penilaian dilakukan sebagai berikut: a) penilaian berbasis kompetensi, b) pergeseran dari penilain melalui tes [mengukur kompetensi pengetahuan berdasarkan hasil saja], menuju penilaian otentik [mengukur semua kompetensi sikap, keterampilan, dan pengetahuan berdasarkan proses dan hasil], c) memperkuat PAP (Penilaian Acuan Patokan) yaitu pencapaian hasil belajar didasarkan pada posisi skor yang diperolehnya terhadap skor ideal (maksimal); d) penilaian tidak hanya pada level KD, tetapi juga kompetensi inti dan SKL; e) mendorong pemanfaatan portofolio yang dibuat siswa sebagai instrumen utama penilaian.

Penilaian otentik merupakan jenis penilaian yang berorientasi pada proses. Proses yang baik biasanya berpengaruh kepada hasil yang baik. Diantara jenis-jenis penilaian otentik adalah penilaian kinerja, penilaian proyek, portofolio dan pengamatan. Penilaian otentik bentuk pengamatan dalam PBA dapat dilakukan setiap jam pelajaran, seperti tergambar dalam tabel berikut:

Tabel 2 Contoh Penilaian Otentik Bentuk Pengamatan dalam PBA

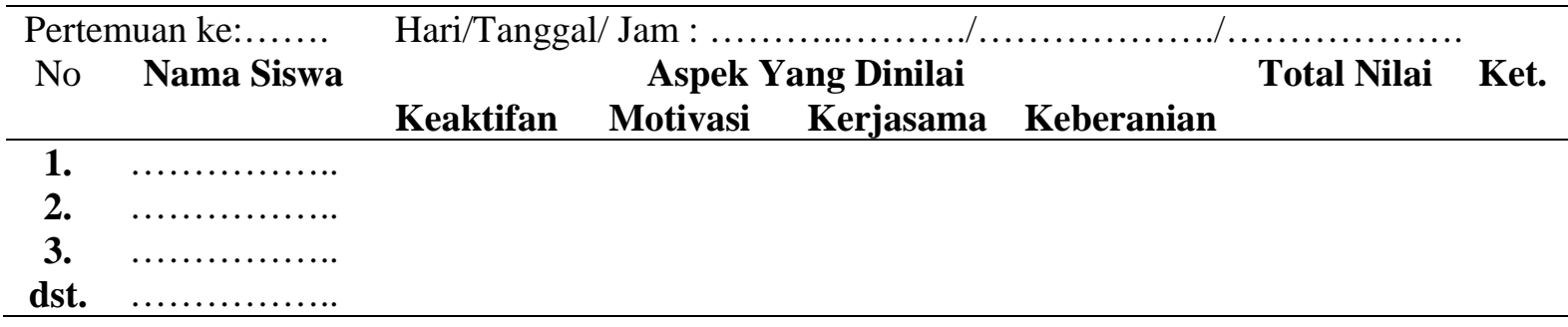

Tabel 3 Contoh Indikator Penilaian Otentik Bentuk Pengamatan dalam PBA

\begin{tabular}{llcccc}
\hline No & \multicolumn{1}{c}{ Aspek yang dinilai } & \multicolumn{2}{c}{ Nilai } & Nilai \\
& & Sangat Aktif & Sedang & Kurang & Maksimal \\
\hline 1. & Keaktifan dalam belajar BA & 3 & 2 & 1 & 3 \\
2. & Motivasi dalam belajar BA & 3 & 2 & 1 & 3 \\
3. & Kerjasama dalam belajar BA & 3 & 2 & 1 & 3 \\
4. & Keberanian dalam belajar BA & 3 & 2 & 1 & 3 \\
\cline { 3 - 6 }
\end{tabular}

Guru dapat merekap nilai siswa tersebut perbulan atau persemester. Cara seperti ini sangat efektif menumbuhkan karakter siswa. Karena siswa menyadari bahwa nilai akhir mereka tidak hanya berdasarkan nilai ujian akhir tetapi juga nilai perpertemuan.

\section{SIMPULAN}

Pengembangan Kurikulum BA berbasis karakter di madrasah dilakukan dengan: (1) memanfaatkan bahan ajar dari teks-teks yang sarat dengan nilai-nilai karakter, (2) memaksimalkan pembelajaran mahfuzhat, (3) menyelenggarakan kegiatan rutin ber-BA, (4) memberikan keteladanan, dan (5) menyelenggarakan pengkondisian.

Pengembangan kurikulum dilakukan berdasarkan landasan, prinsip dan prosedur yang jelas. Landasan pengembangannya mencakup landasan filosofis - yuridis, religius, sosial 
budaya dan kemajuan IPTEK. Prinsip pengembangannya berorientasi kepada kepentingan siswa dan mempertimbangkan kemajuan IPTEK. Prosedur pengembangannya meliputi penyesuaian bahan ajar dengan tuntutan kompetensi peserta didik; pemilihan pendekatan, metode dan strategi; dan pemilihan evaluasi pembelajaran yang sesuai dengan penanaman karakter terhadap siswa.

\section{DAFTAR RUJUKAN}

Akla. 2016. Desain dan Pengembangan Pembelajaran Bahasa Arab Berbasis Pendidikan Karakter di Madrasah. Jurnal Tarbawi yah. Vol. 13, No.1, Edisi Januari - Juni 2016. Hal. 19-35.

Andrianto, T. T. 2011. Mengembangkan Karakter Sukses Anak Di Era Cyber. Yogyakarta: Ar-Ruzz Media.

Hamdun, D. 2016. Pembelajaran Bahasa Arab Berbasis Karakter di Sekolah Dasar. Jurnal FENOMENA, Vol. 8, No 1, tahun 2016. Hal. 39-53.

Hasan, S. H. 2010. Pengembangan Pendidikan Budaya dan Karakter Bangsa. Jakarta: Balitbang Pusat Kurikulum Kemendiknas.

Khasairi, M. 2011. Pemanfaatan Biah Arabiyah di Madrasah/Sekolah dan PT/PTAI. Di dalam AL-ARABI. Jurnal Bahasa Arab dan Pengajarannya. Vol. 9 No. 1 (Juni 2011) hal. $10-18$.

Khasairi, M. 2013. Pemanfaatan Biah Arabiyah di Madrasah/Sekolah dan PT/PTAI. Jurnal Bahasa, Sastra, Seni, dan Pengajarannya. Tahun 41 No. 1 (Pebruari 2013) hal. 60-68.

Koesoema, A. D. 2010. Pendidikan Karakter, Srategi Mendidik Anak di Zaman Global. Jakarta: PT. Grasindo.

Madjid, A. \& Andayani, D. 2011. Pendidikan Karakter Prespektif Islam. Bandung: PT. Remaja Rosdakarya.

Muhaimin. 2009. Rekonstruksi Pendidikan Islam: Dari Paradigma Pengembangan, Manajemen Kelembagaan, Kurikulum hingga Strategi Pembelajaran. Jakarta: PT. Raja Grafindo Persada.

Muhaimin. 2010. Pengembangan Kurikulum Pendidikan Agama Islam di Sekolah, Madrasah dan Perguruan Tinggi. Jakarta: PT. Raja Grafindo Persada.

Muhaimin. 2011. Pemikiran dan Aktualisasi Pengembangan Pendidikan Islam. Jakarta: PT. Raja Grafindo Persada.

Peraturan Menteri Pendidikan dan Kebudayaan Nomor 54, 65, 66, 67, 68, 69, 70, dan 71 Tahun 2013.

Samani, M. \& Hariyanto, M.S. 2011. Konsep dan Model Pendidikan Karakter. Bandung: PT. Remaja Rosdakarya.

Sauri, S. Filosofi, Landasan, Konsep, dan Pengembangan Kurikulum Berbasis Pendidikan Karakter. (Online), (http://haifa-afifah.blogspot.com/2013/ 01/filosofi-landasan-konsepdan_5064.html), diakses 18 Desember 2013.

Sjarkawi. 2006. Pembentukan Kepribadian Anak, Peran Moral, Intelektual, Emosional, dan Sosial, Sebagai Wujud Integritas Membangun Jati Diri. Jakarta: PT Bumi Aksara.

Subandijah. 1999. Pengembangan dan Inovasi Kurikulum. Jakarta: Raja Grafindo Persada. Sunarto \& Hartono, B. Agung. 1999. Perkembangan Perserta Didik, Jakarta: Rineka Cipta. Tim Penyusun. 1997. Kamus Besar Bahasa Indoesia. Jakarta: Departemen Pendidikan dan Kebudayaan - Balai Pustaka. 
Wahab, A. M. 2016. Standarisasi Kurikulum Pendidikan Bahasa Arab di Perguruan Tinggi Keagamaan Islam Negeri. Arabiyât: Jurnal Pendidikan Bahasa Arab dan Kebahasaaraban. Vol. 3, No.1, tahun 2016, hal. 32-51.

Zein, Muhammad. 1991. Asas dan Pengembangan Kurikulum. Yogyakarta: Sumbangsih Offset.

(http://pengawasmadrasah.wordpress.com/category/kurikulum/diakses tangal 15 Desember 2015).

(Online),(Syihabuddin.http://file.upi.edu/Direktori/FPBS/JUR._PEND._BAHASA_ARAB/ 131664371), diakses 16 Desember 2015. 